\title{
Floral morphometric analysis of Prosopis affinis Spreng. (Fabaceae) suggests flexibility of the reproductive system in isolated populations within the Brazilian Pampa
}

\author{
C. Carvalho de Gusmão Lôbo, V.M. Stefenon
}

Carvalho de Gusmão Lôbo C., Stefenon V.M., 2018. Floral morphometric analysis of Prosopis affinis Spreng. (Fabaceae) suggests flexibility of the reproductive system in isolated populations within the Brazilian Pampa. Ann. For. Res. 61(1): $37-47$.

Abstract. Prosopis affinis is native tree of the Brazilian Pampa, recognized as an important species to local culture and economy. Despite the ecological and the economic potential of this tree, studies in Brazil are limited to descriptions of the occurrence sites of P. affinis. Aiming to determine the existence of diversification at floral and/or at population levels for this species, morphological characteristics of inflorescences and flowers of Prosopis affinis growing in the Pampa biome were measured, while the pollen/ ovule ratio and the outcrossing index were determined as an indirect estimate of the species breeding system. No clear reproductive specialization related to flower position in the inflorescence was observed, although basal flowers in the inflorescence presented reduction of the androecium. The results also showed that $P$. affinis presents a breeding system intermediary between facultative autogamy and xenogamy, with upper stamens supporting self-pollination, reduced stamens supporting outcrossing and the likely occurrence of an evolutionary shift at geographical level. These findings highlight the importance of conserving the remnants of $P$. affinis in southern Brazil and further investigate the pollination biology, the breeding system and the genetic diversity of this species, promoting its conservation and better understanding the effect of forest fragmentation in the Pampa biome. Further analyzes comparing isolated and larger continuous populations, as well as estimations of the real outcrossing rate of $P$. affinis through genetic studies and controlled experiments to evaluate auto-compatibility are recommended in order to generate more information about this issue.

Keywords Inhanduvá, outcrossing, plant reproduction, selfing

Authors. Valdir Marcos Stefenon - Universidade Federal do Pampa, Brazil; Camila Carvalho de Gusmão Lôbo - Universidade Federal do Rio Grande do Sul, Brazil.

Manuscript received February $2^{\text {nd }}$, 2018; revised March 22, 2018; accepted March 27, 2018; online first March 28, 2018. 


\section{Introduction}

Adaptive implications of floral traits are related to pollination, breeding and mating system, and to the evolution of plant species (Johnson \& Steiner 2000), even affecting speciation rates (Sargent 2004). These adaptive floral traits can vary spatiotemporally as a result of distinctive selective forces over differences in plant-pollinator interactions generating a complex pattern of floral adaptation between plant populations (Thompson 1999, Etcheverry et al. 2008). In this way, spatial variation in critical floral traits related to plant reproduction could lead us to infer important features of plant life history associated with reproduction process.

The worldwide-spread genus Prosopis L. (Fabaceae) is one of the most important plant taxa providing firewood, timber for local community, as well as edible fruits and forage for wildlife and domestic animals in arid and semi-arid regions (Burkart 1976). However, the deficiency of information about pollination, breeding and mating systems of species from this genus challenges the development of conservation and management strategies for species with economical and ecological importance.

Studies about the breeding system of seven species from section Algarobia of genus Prosopis (P. glandulosa, P. velutina, P. chilensis, P. nigra, P. alba, P. flexuosa and P. ruscifolia) revealed from total outcrossing ( $P$. nigra) to auto-compatible ( $P$. alba) species with up to $28 \%$ of selfing (Bessega et al. 2000).

A useful predictor of breeding system in plants is the ratio of pollen grains to ovules ( $\mathrm{P} / \mathrm{O}$ ratio), a methodology validated by several studies (Cruden 1977, Chouteau et al. 2006, Hentrichet al. 2010) and considered more effective than other morphological characteristic. The $\mathrm{P} / \mathrm{O}$ ratio reflects the efficiency of pollination, as lower values of $\mathrm{P} / \mathrm{O}$ suggest more efficient pollen transfer between conspecifics. This ratio was also shown to be direct related to the successional stage of a species (Cruden
1977). In addition, such proportions of pollen to ovules may be used estimate the outcrossing index (OCI), allowing the inference of autogamous breeding system in plants (Cruden 1977).

Prosopis affinis Spreng. is native to the Brazilian Pampa and recognized as an important tree species to local culture and economy (Marchiori \& Alves 2011). Despite the ecological importance as a pioneer species and the economic potential of this tree, studies in Brazil are limited to descriptions of the occurrence sites of $P$. affinis (Alves \& Marchiori 2010, 2011a, 2011b; Marchiori \& Alves 2010, 2011; Marchiori et al. 2010). Therefore, the conservation and management of $P$. affinis requires informative data about species biology, genetics and reproduction.

Flowers of $P$. affinis are expected to follow the traits of the genus, with hermaphrodite cross-pollinated flowers, bees as the main pollinator, and floral specialization along the inflorescence. However, variation in these traits could occur in response to environment gradients or disturbances in abiotic or biotic conditions (Johnson \& Steiner 2000, Busch 2011, Niet \& Johnson 2012). Population fragmentation may decrease seed dispersal and affect the plant-pollinators interactions, disturbing fitness parameters (Aguilar et al. 2006, Stefenon et al. 2016) and the plant population genetic structure (Jacquemyn et al. 2012, Lemos et al. 2015, Nagel et al. 2015).

Since the middle of the XVIII century, the Brazilian Pampa has an economy based on monoculture and livestock, exploring the grass-dominated vegetation (Roesch et al. 2009). Such economic exploitation hinders the expansion of the forest formations and increases the genetic and evolutionary consequences of fragmentation in tree species within this biome (Lemos et al. 2014, Nagel et al. 2015, Stefenon et al. 2016). Thus, considering the fragmented distribution of the Brazilian populations of $P$. affinis within a disturbed matrix of agricultural lands and the indirect effects of habitat fragmentation in plant breeding sys- 
tems, such isolated populations of this species might undergo a process of adaptation through transition from specialized to general pollination systems with mixed breeding system, giving the fact that pollinator availability might also oscillate. Aiming to test this hypothesis and to indirectly characterize the species breeding system, we examined the morphological characteristics of inflorescences and flowers of $P$. affinis from natural populations in the Brazilian Pampa and estimated the $\mathrm{P} / \mathrm{O}$ ratio and the outcrossing index of this species. We intended to answer the following questions: (i) is there significant differentiation in floral morphology within the same inflorescence, reflecting some degree of diversification at floral level? (ii) Is there some significant differentiation in floral morphology among populations, reflecting some degree of diversification at geographical level? (iii) Are the estimations of $\mathrm{P} / \mathrm{O}$ ratio and $\mathrm{OCI}$ characteristic of species with mixed breeding system?

\section{Material and methods}

\section{Studied species}

The genus Prosopis presents at least 40 species distributed in Asia, Africa and predominantly in America where $70 \%$ of the species can be found (Ribasky et al. 2009). Prosopis affinis is a tree species native to southern Brazil, Uruguay, and eastern Argentina (Pasiecznik et al. 2001). This is a primarily outcrossing, insect pollinated tree species, currently classified as vulnerable in the Rio Grande do Sul State, Brazil (FZB 2014) due to the fragmented distribution and small size of the majority of the populations. Occurring exclusively in the Pampa biome, only six populations of $P$. affinis are documented in Brazil (Alves \& Marchiori 2010, 2011a, 2011b; Marchiori \& Alves 2010, 2011; Marchiori et al. 2010).

\section{Study sites}

Three natural populations of $P$. affinis occurring as isolated formations in disturbed environments near agricultural systems of rice, soybean and cattle ranching within the Brazilian Pampa were investigated. Inflorescences were collected during local summer (February) in populations Quaraí (30¹2'50'S, 56 32'7’'W),

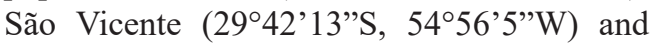

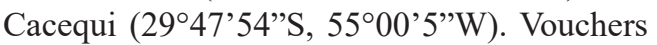
were deposited in the Herbarium Bruno Edgar Irgang (HBEI) at Universidade Federal do Pampa, Campus São Gabriel. The vegetation of this area is characterized as steppic-savannah (Roesch et al. 2009) and climate is classified as Cfa (Humid subtropical climates) according to Köppen (Kuinchter \& Buriol 2001).

\section{Morphological differentiation among flowers}

Total number of flowers per inflorescence ( $n$ =22) was counted under a stereomicroscope using 400X magnification. Thirty flowers collected from eight individuals were sampled from basal, middle and apical portions of the inflorescence (Figure 1A), totalizing 90 flowers analyzed in each population. Floral morphology was characterized for individual flowers by measuring: (1) the height of the calyx, (2) the height of the corolla, (3) the height of the upper stamens, (4) the height of the lower stamens, (5) the height of the style, (6) the basal diameter of the calyx and (7) the diameter of the corolla (Figure 1B). All measures were obtained using a stereomicroscope with scales. A multivariate analysis (Principal Component Analysis, PCA) was employed to evaluate the morphometric differentiation among samples of the three populations. Since the floral differentiation may occur in distinct positions of the flower in the inflorescence, characterizing a reproductive distinction within the inflorescence, the correlation among all samples was evaluated through the nine morphometric measures in each of the three floral positions 

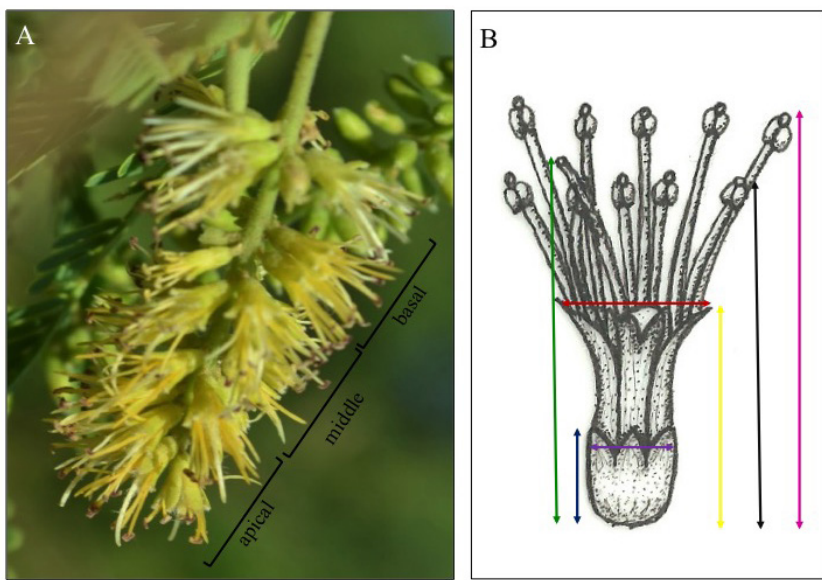

Figure 1 (A) Inflorescence of P. affinis, showing the floral positions considered: basal, middle and apical. (B) Scheme of the floral traits measured. The double-arrowed lines represent the dimensions of each measured trait: yellow line: height of the corolla, green line: height of the style, blue line: height of the calix, red line: diameter of the corolla, violet line: diameter of the calix, black line: height of the lower stamens, pink line: height of the upper stamens.
$=1$ ), and spatial relationship of stigma and anthers (stigmas and anthers at the same level and possible contact between anthers and stigma $=0$; stigma and anther spatially separated and unlikely contact $=1$ ).

\section{Statistical analysis}

Statistical differences of means of the measured traits among populations and flower positions and of the $\mathrm{P} / \mathrm{O}$ ration between populations were verified with Kruskall-Wallis hypothesis test and Dunn's test a posteriori $(\alpha=$ $0.05)$ once checked for normality of samples distribution with Lilliefors test and its homogeneity with Levene test, using the software Bioestat 5.0. (basal, middle and apical), totalizing 27 morphometric measures combined. The multivariate analysis was performed using the software PAST 3.04 (Hammer et al. 2001).

\section{Estimations of reproductive parameters}

The pollen/ovule ratio ( $\mathrm{P} / \mathrm{O}$ ratio) and the outcrossing index (OCI) were used to indirectly estimate the breeding system of $P$. affinis. The pollen-ovule ratio was determined by dividing the number of pollen grains per flower by the number of ovules per flower (Cruden 1977) for each floral position (basal, middle and apical) from flowers of populations Cacequi and Quaraí (there was not buds in the inflorescences collected from São Vicente).

The outcrossing index was estimated according to Cruden (1977), as the sum of ascribed values for three floral features: diameter of the flower (corolla up to $1.0 \mathrm{~mm}=0 ; 1-2 \mathrm{~mm}=1$; $2-6 \mathrm{~mm}=2 ;>6 \mathrm{~mm}=3)$, temporal separation of anthers dehiscence and stigma receptivity (homogamy and protogyny $=0$; protandry 40

\section{Results}

\section{Measurements of floral morphology}

Prosopis affinis inflorescences presented in average $117.13 \pm 29.50$ yellowish, tubular hermaphrodite flowers (Figure 1A). Basal, middle and apical flowers have five lower and five upper stamens and a single style (Figure 1B). Interestingly, while the upper stamens may promote self-pollination, flower with style higher or with same size of the stamens were observed in $23.33 \%$ of basal flowers, $15.55 \%$ of middle flowers and $16.66 \%$ of apical flowers, a pattern that may avoid the occurrence of self-pollination.

The height of lower and upper stamens was significantly different $(p<0.05)$ across basal, middle and apical positions in the inflorescence in all populations (Figure 2A-C; Table 1). Stamens were shorter in the basal flowers for all populations. The longest ones were the middle flowers in populations Cacequi and 


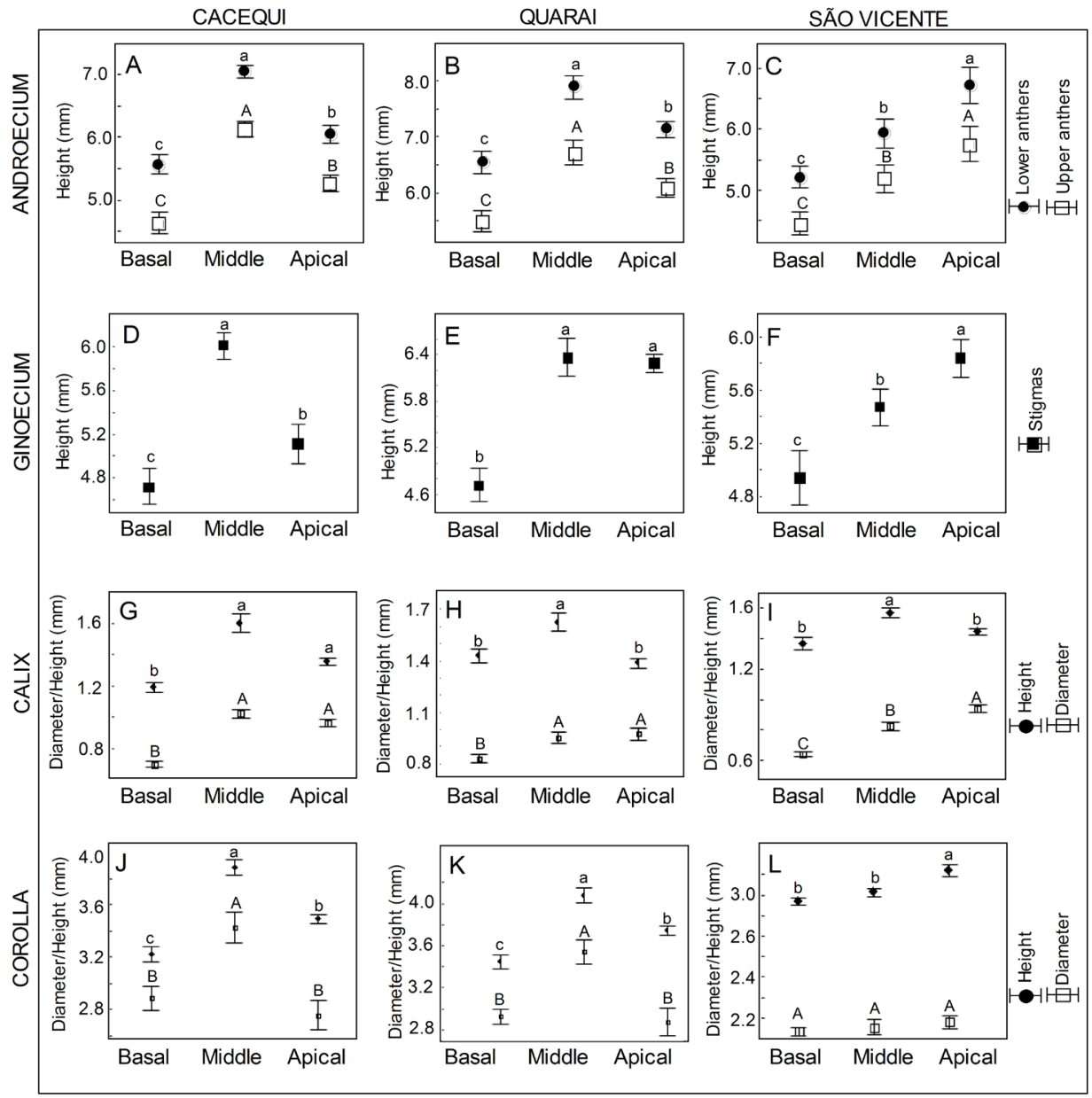

Figure 2 Mean values and variation in standard error of the measured floral traits of Prosopis affinis in populations Cacequi, Quaraí and São Vicente, in the Brazilian Pampa.

Quaraí (Figure 2A-B, Table 1), while the apical flowers were the longest in population São Vicente (Figure 2C, Table 1). The same pattern was observed for the height of the styles, with shorter structures in the basal position (Figure 2D-F, Table 1). However, the longest styles diverged in each population. In population Cacequi, the longest styles were found in the middle position of the inflorescence, while the longest styles in population São Vicente were observed in the apical position (Figure 2F, Table 1). In population Quaraí, flowers from the middle and apical positions presented styles longer than the basal ones, but not statistically different from each other (Table 1).

The diameter of the calyx of basal flowers was smaller in all populations (Figure 2G-I, Table 1). In populations Cacequi and Quaraí, flowers from the middle and apical positions did not differ statistically, whilst the apical flowers are significantly larger in population São Vicente. Concerning the height of the calyx, the longest ones were found in the middle position of the inflorescence, although not different from apical flowers in population Cacequi (Figure 2H, Table 1). In populations 


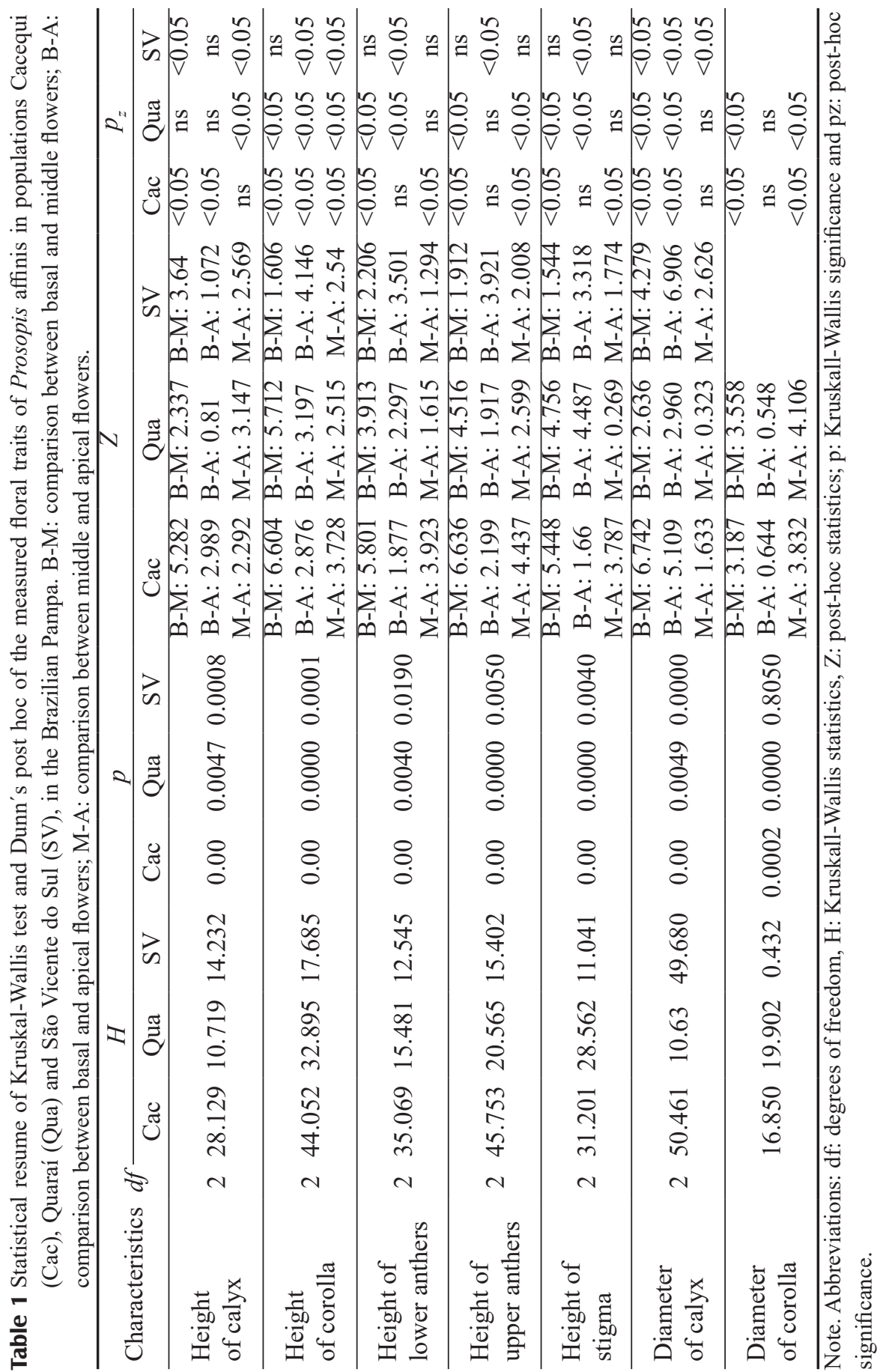


Quaraí and São Vicente, basal and apical flowers did not differ in height of the calyx.

Measures of the corolla's diameter and height revealed no consistent pattern over populations (Figure 2J-L, Table 1). In population Cacequi, flowers of the middle position revealed larger diameter and height, while the diameter of basal and apical flowers did not differ and the height of basal flowers is the smallest (Figure 2J, Table 1). The diameter of basal and apical flowers did not differ in population Quaraí (Figure 2H, Table 1). In population São Vicente, no difference was observed for the diameter of corolla across the flower positions, while apical flowers revealed the largest height and basal and middle flowers did not differ in this population (Figure 2I, Table $1)$.

\section{Among populations differentiation}

Multivariate analysis (Figure 3A) revealed differentiation for some samples from each population, mainly for samples from São Vi- cente and Quaraí, suggesting relatively differentiated trends among populations concerning the morphometric traits measured. The main characters related to this differentiation for population São Vicente were the height of the stamens in apical flowers [height of upper stamens in apical flowers (HUAA), height of lower stamens in apical flowers (HLAA) and total height of stamens in apical flowers (THA); Axis 2 in Figure 3A] and the height of the stamens in median and basal flowers for population Quaraí [height of upper stamens in median flowers (HUAM), total height of stamens in median flowers (THM), height of upper stamens in basal flowers (HUAB) and total height of stamens in basal flowers (THB); Axis 1 in Figure 3A].

\section{Estimations of $\mathbf{P} / \mathrm{O}$ ratio and $\mathrm{OCI}$}

Although the morphological traits suggest a tendency towards occurrence of outcrossing, the mean $\mathrm{P} / \mathrm{O}$ ratios estimated in Cacequi (424.33 \pm 233.91 for basal flow-
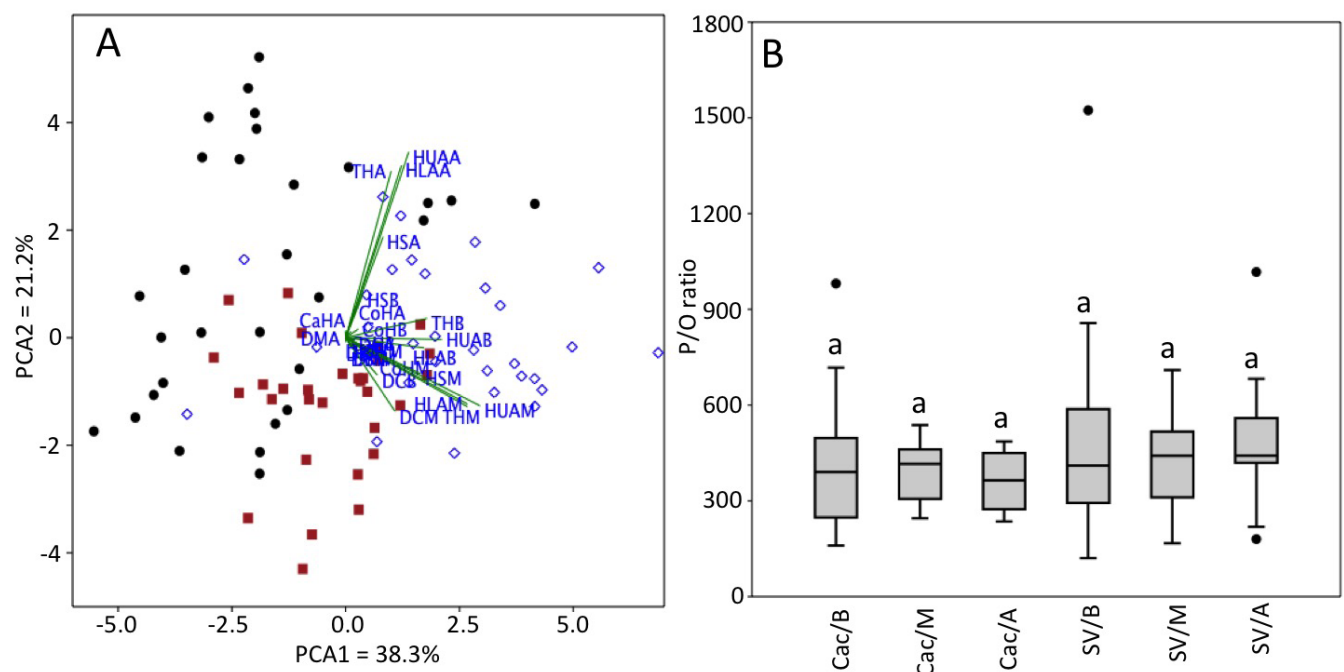

Figure 3 (A) Multivariate analysis (PCA) of samples from populations Cacequi (red squares), São Vicente (black dots) and Quaraí (blue diamonds), based on 27 floral traits combined. (B) Pollen/ovule $(\mathrm{P} / \mathrm{O})$ ratio in flowers of $P$. affinis in basal flowers (Cac/B and SV/B), middle flowers (Cac/M and $\mathrm{SV} / \mathrm{M})$ and apical flowers (Cac/A and SV/A) from populations Cacequi (Cac) and São Vicente (SV), in the Brazilian Pampa. Dots represent outlier samples. 
ers, $389.66 \pm 95.99$ for middle flowers and $362.02 \pm 90.85$ for apical flowers; Figure 3B) and in São Vicente $(454.84 \pm 295.60$ for basal flowers, $421.04 \pm 140.24$ for middle flowers and $487.67 \pm 193.113$ for apical flowers, Figure 3B) did not differ statistically for flower positions and are intermediary between facultative autogamy and xenogamy (Cruden 1977), suggesting a flexible reproductive system. In addition, this value corresponds to $\mathrm{P} / \mathrm{O}$ ratios observed in intermediary to highly disturbed landscapes with pioneer species, an environment where floral self-compatibility and/or self-pollination usually occurs, mainly compensating the low incidence of pollinators. Similarly, the estimated outcrossing index was OCI = 2 (corolla with 2-6 $\mathrm{mm}=2$; homogamy $=0$; possible contact between anther and stigma $=$ 0 ), characteristic of plants that are self-compatible and autogamous, with a limited degree of outcrossing (Cruden 1977). Plants with OCI $=2$ includes native colonizers and plants growing in highly disturbed habitats (Cruden 1977). The obtained value of seed/ovule ratio was $0.503 \pm 0.189$, pointing to medium taxa of ovule abortion.

\section{Discussion}

Differentiation in floral morphology suggests ongoing evolutionary shift but no pattern of specialization for pollination

The tubular yellow hermaphrodite flowers of $P$. affinis are expected to attract insects, mainly bees, as observed in Uruguay (Galera 2000) and proposed for other Prosopis species (Vossler 2014). Even though hermaphrodite flowers are common in Mimosoideae, they may be functionally andromonoecious as few Prosopis and Inga (Hoc et al. 1993, Barros et al. 2013) or gynomonoecious as Acacia (Tybirk 1997), and floral differentiation within the inflorescence may be related to ongoing evolutionary shifts.

The reduced stamens observed in some 44 flowers of $P$. affinis in this study may represent a kind of sex allocation, precluding self-pollination in these flowers. Such female-male asymmetry may be related to flowers evolution considering that most of the modifications related to floral specialization are associated to inflorescence positions and size of gynoecium (Diggle 2003).

In turn, morphological characteristics of calyx and corolla are direct related with pollinator attraction. While height of stamens revealed evidences of an evolutionary shift, no pattern of specialization related to pollination can be proposed based on the measurements of the calyx and corolla performed in the Pampean populations.

\section{Long-term isolation may have caused geo- graphic diversification in floral morphology among populations}

The regional differentiation in characteristics of the inflorescences and/or flowers at population level determines a phase of the evolutionary variation in reproductive traits across the geographic range of a species (Etcheverry et al. 2008). Thus, the pattern of differentiation among populations caused by the height of stamens may represent the beginning of such a floral specialization related to inflorescence portions in the Brazilian populations of P. affinis. Expansion of gallery forest species in this region of the Brazilian Pampa started about 5,000 years before present (Behling et al. 2005). Considering that $P$. affinis populations were founded in the region at that time and assuming a generation interval of 15 years for the species, more than 330 generations have passed since establishment. Considering the patterns of fragmented landscape of the Brazilian Pampa concerning forest formations (Roesch et al. 2009), much likely no connection among populations existed since then and those populations experience a considerable long time of isolation and evolutionary shift. Since the evaluated floral traits have a genetic control, the geographic and reproductive isola- 
tion of the studied populations of $P$. affinis for such a long period may have contributed to the differentiation observed among populations.

\section{$\mathrm{P} / \mathrm{O}$ ratio and $\mathrm{OCl}$ suggest a flexible repro- ductive system between facultative autogamy and xenogamy}

The $\mathrm{P} / \mathrm{O}$ ratio estimated for $P$. affinis in this study was lower than means reported by Cruden (1977) for the Mimosoideae Caliandra palmeri $(863.3 \pm 42.3)$, but similar to $C$. calistemon (526.5 \pm 59.0$)$, C. kimthii $(328.7 \pm 36.6)$ and $C$. anomala $(246.1 \pm 24.5)$. Even though such relatively low $\mathrm{P} / \mathrm{O}$ ratio is a feature of $\mathrm{Mi}$ mosaceae, the studied populations of $P$. affinis may be following such selection regarding economy in pollen production and a relative change in sex allocation through the shortening of stamens observed in some flowers.

In comparison to other xenogamous species, Mimosoideae subfamily present low values of $\mathrm{P} / \mathrm{O}$ ratio (Cruden 1977). These plants present low fecundity and invest maximal energy in pollen production. However, the reproductive benefit is reasonably high when pollination is effective. As proposed by Mazer \& Delesalle (1998), autogamous flowers would evolve favoring an effective $\mathrm{P} / \mathrm{O}$ ratio consistent among flowers, producing as much pollen as needed to safeguard fertilization. On the other hand, outcrossing plants may experience selection towards a variation in sex allocation, conditional to temporal changes in the richness and efficiency of pollinators (Delesalle et al. 2008).

\section{Outlook and perspectives}

Flowers of $P$. affinis present upper stamens that support self-pollination, while the presence of flowers with reduced stamens supports the outcrossing. In addition, the estimations of $\mathrm{P} / \mathrm{O}$ ratios and $\mathrm{OCI}$ are equivalent to species with a breeding system intermediary between facultative autogamy and xenogamy. Such estimations are also in accordance with the fragmented and disturbed agricultural matrix where populations occur, because pollinators may be less abundant and less effective, prejudicing outcrossing. In addition, since the multivariate analysis revealed flowers presenting a significant divergence among populations in relation to floral morphology, an evolutionary shift at geographical level may be in course. On the other hand, reproductive differentiation within inflorescence should be refuted since the $\mathrm{P} / \mathrm{O}$ ratio in each population and overall did not differ statistically for flower positions, even though a higher number of flowers with reduction of stamens' height were observed in basal flowers, in comparison to other positions. Substantial evidence on this likely evolutionary shift might be obtained from further analyzes comparing isolated and larger continuous populations. In addition, genetic studies aiming to estimate the real outcrossing rate of $P$. affinis and controlled experiments to evaluate auto-compatibility are needed in order to get more information about this issue.

As a general conclusion, this study shows that $P$. affinis presents a breeding system intermediary between facultative autogamy and xenogamy, with upper stamens supporting self-pollination, reduced stamens supporting outcrossing and the likely occurrence of an evolutionary shift at geographical level. These findings highlight the importance of conserving the remnants of $P$. affinis in southern Brazil and further investigate the pollination biology, the breeding system and the genetic diversity of this species, in order to promote its conservation and better understand the effect of forest fragmentation in the Pampa biome.

\section{Acknowledgements}

Authors knowledge the financial support provided by CNPq/Brazil (Process 442995/20148), FAPERGS and PROPESQ/UNIPAMPA. We thank Dr. Rubem Samuel de Ávila Jr. by the helpful discussions and comments on an 
earlier version of this manuscript and MSc. Rafael Plá Matielo Lemos by field assistance.

\section{References}

Aguilar R., Ashworth L., Galetto L., Aizen MA., 2006. Plant reproductive susceptibility to habitat fragmentation: review and synthesis through a meta analysis. Ecological Letters 9: 968-980.

Alves F.S., Marchiori J.N.C., 2010. O inhanduvá (Prosopis affinis Spreng.) no Rio Grande do Sul. 2 - Ocorrência natural na região do Parque do Jarau, Quaraí [The inhanduvá (Prosopis affinis Spreng.) in Rio Grande do Sul. 2 - Natural occurrence in the region of Jarau Park, Quaraí]. Balduinia 25: 1-9.

Alves F.S., Marchiori J.N.C., 2011a. O inhanduvá (Prosopis affinis Spreng.) no Rio Grande do Sul. 5 - Ocorrência natural na várzea do rio Santa Maria, Rosário do Sul [The inhanduvá (Prosopis affinis Spreng.) in Rio Grande do Sul. 5 - Natural occurrence in the floodplain of the Santa Maria river, Rosário do Sul]. Balduinia 27: $1-7$.

Alves F.S., Marchiori J.N.C., 2011b. O inhanduvá (Prosopis affinis Spreng.) no Rio Grande do Sul. 7 - Ocorrência natural na planície de inundação do arroio Itapororó, município de [The inhanduvá (Prosopis affinis Spreng.) in Rio Grande do Sul. 7 - Natural occurrence in the floodplain of the Itapororó stream, municipality of Alegrete] . Balduinia 28: 1-7.

Barros E.C. de O., Webber A.C., Machado I.C., 2013. Limitação de polinizadores e mecanismo de autoincompatibilidade de ação tardia como causas da baixa formação de frutos em duas espécies simpátricas de Inga (Fabaceae - Mimosoideae) na Amazônia Central [Pollinators limitation and delayed action autoincompatibility mechanism as causes of low fruit formation in two sympatric species of Inga (Fabaceae - Mimosoideae) in Central Amazonia]. Rodriguésia. 64: 37-47

Behling H., Pillar V.P., Bauermann S.G., 2005. Late Quaternary grassland (Campos), gallery forest, fire and climate dynamics, studied by pollen, charcoal and multivariate analysis of the São Francisco de Assis core in western Rio Grande do Sul (southern Brazil). Review of Palaeobotany and Palynology 133: 235-248.

Bessega C., Ferreyra L., Julio N., Montoya S., Saidman B., Vilardi J.C., 2000. Mating system parameters in species of genus Prosopis (Leguminosae). Hereditas 132: 19-27.

Busch J.M., 2011. Demography, pollination, and Baker's law. Evolution 65: 1511-1513.

Burkart A., 1976. A monograph of the genus Prosopis (Leguminosae sub-fam. Mimosoideae). Journal of the Arnold Arboretum 57: 219-249; 450-455.

Chouteau M., Barabe' D., Gibernau M., 2006. Pollenovule ratios in some Neotropical Araceae and their putative significance. Plant Systematics and Evolution
257: 147-157.

Cruden R.W., 1977. Pollen-ovule ratios: a conservative indicator of breeding systems in flowering plants. Evolution 31: 32-46.

Delesalle V.A., Mazer S.J., Paz H., 2008. Temporal variation in the pollen: ovule ratios of Clarkia (Onagraceae) taxa with contrasting mating systems: field populations. Journal of Evolutionary Biology 21: 310-23.

Diggle P.K., 2003. Architectural effects on floral form and function: a review. In: Stuessy T., Horandl E., Mayer V., (eds.), Deep morphology: toward a renaissance of morphology in plant systematics. Koeltz: Konigstein.

Etcheverry A.V., Alemán M.M., Fleming T.F., 2008. Flower morphology, pollination biology and mating system of the complex flower of Vigna caracalla (Fabaceae: Papilionoideae). Annals of Botany 102: 305-316

Fundação Zoobotânica Do Rio Grande Do Sul. 2014. Taxons da flora nativa do estado Rio Grande do Sul ameaçadas de extinção. Governo do Estado do Rio Grande do Sul [Taxons of the native flora of Rio Grande do Sul state threatened with extinction]. Government of the State of Rio Grande do Sul.

Galera F., 2000 Los algarrobos: las especies del género Prosopis (algarrobos) de América Latina con especial énfasis en aquellas de interés económico [The carob trees: the species of the genus Prosopis (carob trees) of Latin America with special emphasis on those of economic interest]. Córdoba: UNC-Secretaría de Ciencia y Tecnología, 269 p.

Hammer Ø., Harper D.A.T., Ryan P.D., 2001. Past: Paleontological statistics software package for education and data analysis. Palaeontologia Electronica 4: 4

Hentrich H., Kaiser R., Gottsberger G., 2010. Floral biology and reproductive isolation by floral scent in three sympatric aroid species in French Guiana. Plant Biology 12: 587-596.

Hoc P.S., Agulló M.A., Palacios R., 1994. Stylar trimorphism in four functionally andromonoecious Prosopis species (Mimosaceae). Plant Systematics and Evolution 190: 143-156.

Jacquemyn H., De Meester L., Jongejans E., Honnay O., 2012. Evolutionary changes in plant reproductive traits following habitat fragmentation and their consequences for population fitness. Journal of Ecology 100: 76-87.

Johnson S.D., Steiner K.E., 2000. Generalization versus specialization in plant pollination systems. Trends in Ecology and Evolution 15: 140-143.

Kuinchter A., Buriol G.A., 2001. Clima do estado do Rio Grande do Sul segundo a classificação climática de Köppen e Thornthwaite [Climate of the Rio Grande do Sul State according to the climatic classification of Köppen and Thornthwaite]. Disciplinarum Scientia 2: 171-182.

Lemos R.P.M., D’Oliveira C.B., Rodrigues C.R., Roesch L.F.W., Stefenon V.M., 2014. Modeling distribution of Schinus molle L. in the Brazilian Pampa: insights on vegetation dynamics and conservation of the biome. Annals of Forest Research 57: 205-214. 
Lemos R.P.M., D’Oliveira C.B., Stefenon V.M., 2015. Genetic structure and internal gene flow in populations of Schinus molle (Anacardiaceae) in the Brazilian Pampa. Tree Genetics \& Genomes 11: 75

Marchiori J.N.C., Alves F. da S., 2010. O Inhanduvá (Prosopis affinis Spreng.) no Rio Grande do Sul. 1 Embasamento fitogeográfico e pendências terminológicas [The Inhanduvá (Prosopis affinis Spreng.) in Rio Grande do Sul. 1 - Phytogeographic background and terminological issues]. Balduinia 24: 1-11.

Marchiori J.N.C., Alves F. da S., Paz, E.A., 2010. O Inhanduvá (Prosopis affinis Spreng.) no Rio Grande do Sul. 3 - Parque da Cabanha do Loreto, São Vicente do Sul [The Inhanduvá (Prosopis affinis Spreng.) in Rio Grande do Sul. 3- Park Cabanha do Loreto, São Vicente do Sul]. Balduinia 25: 22-31.

Marchiori J.N.C., Alves F. da S., 2011. O Inhanduvá (Prosopis affinis Spreng.) no Rio Grande do Sul. 8 - Aspectos fitogeográficos [The Inhanduvá (Prosopis affinis Spreng.) in Rio Grande do Sul. 8 - Phytogeographical aspects]. Balduinia 29: 13-20.

Mazer S.J., Delesalle V.A., 1998. Contrasting variation within and covariation between gender-related traits in autogamous versus outcrossing species: alternative evolutionary predictions. Evolutionary Ecology 12: 403-425.

Nagel J.C., Ceconi D.E., Poletto I., Stefenon V.M., 2015. Historical gene flow within and among populations of Luehea divaricata in the Brazilian Pampa. Genetica 143: 317-329.

Niet Van der T., Johnson S.D., 2012. Phylogenetic evidence for pollinator-driven diversification of angio- sperms. Trends in Ecology and Evolution 27: 353-361. Pasiecznik N.M., Felker P., Harris P.J.C., et al., 2001. The Prosopis juliflora - Prosopis pallida Complex: A Monograph. HDRA, Coventry, 172 p. UK.

Ribasky J., Drumond M.A., Oliveira V.R., et al., 2009. Algaroba (Prosopis juliflora): Árvore de uso múltiplo para a região Semiárida Brasileira [Algaroba (Prosopis juliflora): Multiple-use tree for the Brazilian semi-arid region. Colombo. 240p.

Roesch L.F.W., Vieira F.C.B., Pereira V.A., Schünemann A.L., Teixeira I.F., Senna A.J.T., Stefenon V.M., 2009. The Brazilian Pampa: A Fragile Biome. Diversity 1: 182-198.

Sargent R.D., 2004. Floral symmetry affects speciation rates in angiosperms. Proceedings of the Royal Society of London B 271: 603-608.

Stefenon V.M., Nagel J.C., Ceconi D.E., Poletto I., 2016. Evidences of genetic bottleneck and fitness decline in Luehea divaricata populations from southern Brazil. Silva Fennica 50: 1566

Thompson J.N., 1999. Specific hypotheses on the geographic mosaic of coevolution. The American Naturalist 153: S1-S14.

Tybirk K., 1997. Reproductive biology and evolution of the genus Acacia. Bulletin of the International Group for the Study of Mimosoideae 20: 45-53.

Vossler F.G., 2014. A tight relationship between the solitary bee Calliopsis (Ceroliopoeum), Laeta (Andrenidae, Panurginae) and Prosopis pollen hosts (Fabaceae, Mimosoideae) in xeric South America woodlands. Journal of Pollination Ecology 14: 270-277. 